\title{
Animal utilization based on local knowledge in Ciletuh Geopark, Ciemas Subdistrict, Sukabumi, West Java, Indonesia
}

\author{
INDRI WULANDARI ${ }^{1,2,3}$, SYA SYA SHANIDA ${ }^{3, \vartheta}$, TEGUH HUSODO ${ }^{1,2,3}$, ERRI NOVIAR MEGANTARA $^{1,2,3}$, \\ DEDE TRESNA ${ }^{3}$ \\ ${ }^{1}$ Department of Biology, Faculty of Mathematics and Natural Sciences, Universitas Padjadjaran. J1. Raya Bandung-Sumedang Km 21, Jatinangor, \\ Sumedang 45363, West Java, Indonesia. Tel.+62-22-7796412 ext. 104, Fax.+62-22-7794545. ^email: syasyashanida@gmail.com \\ ${ }^{2}$ Program of Environmental Science, School of Graduates, Universitas Padjadjaran. Jl. Sekeloa, Coblong, Bandung 40134, West Java, Indonesia \\ ${ }^{3}$ Center of Environment and Sustainable Science, Directorate of Research, Community Services and Innovation, Universitas Padjadjaran. Jl. Raya \\ Bandung-Sumedang Km 21, Jatinangor, Sumedang 45363, West Java, Indonesia
}

Manuscript received: 3 June 2019. Revision accepted: 2 September 2019.

\begin{abstract}
Wulandari I, Shanida SS, Husodo T, Megantara EN, Tresna D. 2019. Animal utilization based on local knowledge in Ciletuh Geopark, Ciemas Subdistrict, Sukabumi, West Java, Indonesia. Biodiversitas 20: 2781-2789. Ciletuh Geopark has high biodiversity but has not been supported by local knowledge about the use of animals to support sustainable development. This study aims to investigate: (i) the number of species that are used, (ii) distribution of local knowledge about animals using, and (iii) the dependency of communities on creatures in Ciletuh Geopark, Ciemas Subdistrict, Sukabumi. Mixed methods of qualitative (semi-structured interviews) and quantitative methods (proportional random sampling) were applied in this study. The community uses 153 species, consisting 58 Avifauna species, 13 mammals species, nine Herpetofauna species, three insects species, 16 species of freshwater fish, 43 species of seawater fish, two Mollusca species, and nine crustacean species. Utilization of fauna is not distributed in each village. Animals using of Avifauna, Herpetofauna, insects, and mammals tend to be utilized by people of Girimukti Village. Seawater fish, Mollusca, and crustaceans tend to be utilized by Ciwaru Village, while freshwater fish tend to be used in each village, except Girimukti and Cibenda Village. Utilization of fauna in Ciemas Subdistrict has begun to be abandoned, although several people still use them.
\end{abstract}

Keywords: Animal utilization, Ciemas, Ciletuh Geopark, Sukabumi

\section{INTRODUCTION}

Ciletuh-Palabuhanratu Geopark of West Java, Indonesia is an area with a concept of tourism-based education, and conservation of geological diversity, biodiversity, and cultural diversity to support sustainable development. Ciletuh-Palabuhanratu Geopark is divided into several regions, one of them is Ciletuh Geopark. Ciletuh Geopark is located in Ciemas Subdistrict, Sukabumi District, West Java, Indonesia. This area has a uniqueness compared to other geoparks because Ciletuh Geopark is shaped like an amphitheater. Ciletuh Geopark has a diverse ecosystem ranging from marine ecosystems in the lowlands to forest ecosystems in the highlands so that Ciletuh Geopark has a variety of biodiversity (Gunawan 2018).

Based on exploratory studies found various species of fauna in Ciletuh Geopark, including avifauna as many as 88 species from 41 families, while 28 species among them have REEPS status (Rare, Endemic, Endangered, and Protected Species). Mammals species are found as many as 25 species from 16 families and 7 orders, whereas 10 species among them have REEPS status. Species of herpetofauna are found as many as 35 species, including 11 species of Amphibian (5 families) and 24 species of Reptile (8 families). As many as 11 species of herpetofauna have REEPS status. Besides exploratory study, in 2016 was conducted the interview about biodiversity in Ciletuh Geopark, Ciemas Subdistrict, Sukabumi, West Java,
Indonesia. According to Partasasmita et al. (2016) that Javan Leopard is often hunted, traded, and consumed by the local community in Girimukti Village. According to Ramadhani (2018) unpublished, that several birds are also consumed by the local community in Girimukti Village. Based on the previous studies, we should reveal the information of local knowledge about animals, especially animal utilization.

The high biodiversity in Ciletuh Geopark has not been completed with information of local knowledge about animal utilization, so that it is necessary to study about them. To be able to support sustainable development, good and wise management is needed (Wulandari et al. 2018), one of which is the local knowledge in Ciletuh Geopark. However, the knowledge that is owned by the community is only conveyed in oral form from generation to generation, so that their knowledge is threatened with being lost because it is not documented in writing.

The study of animal utilization in Ciletuh Geopark has never been carried out, while Geopark itself has high biodiversity around the community environment, so it is important to document local knowledge about animal utilization in Ciletuh, Ciemas Subdistrict, Sukabumi District, West Java Province, Indonesia. This study aims to investigate: (i) the number of species that are used, (ii) distribution of local knowledge about animals using, and (iii) the dependency of communities on creatures in Ciletuh Geopark. 


\section{MATERIALS AND METHODS}

\section{Study area}

Based on the Central Bureau of Statistics of Ciemas Subdistrict (2017) that the topography of Ciemas Subdistrict consists of hilly terrain and mountains, with slopes varying between $0.3 \%, 8-15 \%$, and $>40 \%$. Relatively flat land with a slope between $0.3 \%$ is found in the central part of the district and around the Ciletuh River, a slope of $15-25 \%$ is found in the North and South, while a slope of $>40 \%$ is found in the central part in Panenjoan area. The elevation of Ciemas Subdistrict is between 0-500 meters above sea level. The climate in Ciemas Subdistrict is still influenced by regional climatic conditions in the Sukabumi District which has a tropical wet climate. The rainfall heavily influenced by the wind that blows from Australia and Asia with temperatures ranging from 20$32^{\circ} \mathrm{C}$.

\section{Procedures}

\section{Mixed methods}

The study was conducted using a mixed-method approach, a combination of qualitative and quantitative (Newing et al. 2011; Albuquerque et al. 2014). This mixedmethod is carried out with the assumption that collecting various types of data that are considered best can provide a thorough understanding of the problem under study (Creswell 2009).

\section{Semi-structured interview}

Qualitative data collection is carried out by semistructured interviews. The semi-structure interview was undertaken by deep interview with competent informants (local experts) (Iskandar et al. 2016). Interview was conducted with guidelines for interviews that had been made previously and could be developed during the interview (Husodo et al. 2019) Informants were chosen by the snowball sampling technique. The categorization of the informants in this study are poachers, community elders, and animal traders.

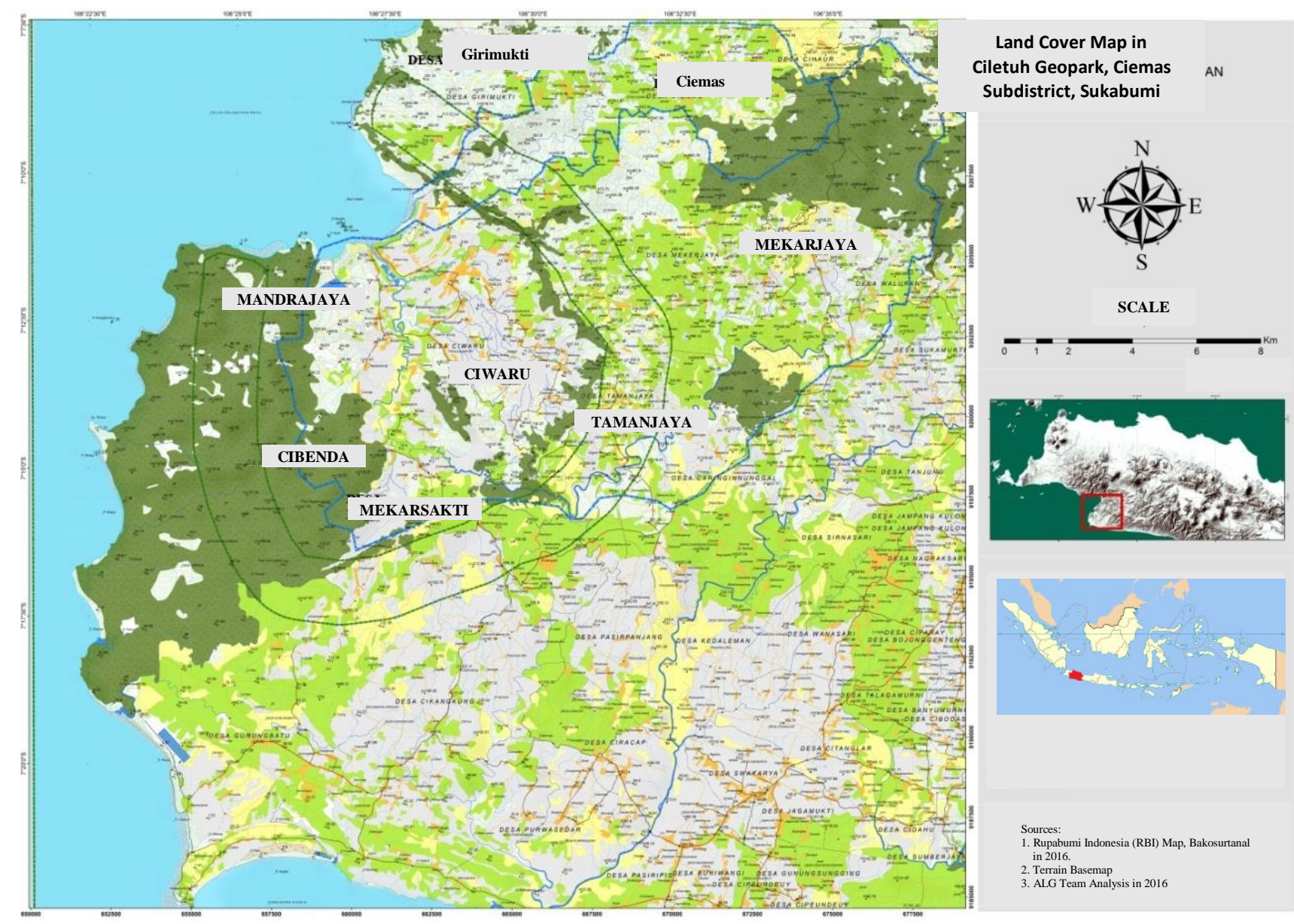

Figure 1. Study area in Ciletuh Geopark, Ciemas Subdistrict, Sukabumi, West Java, Indonesia (7¹3’7.31'S 106 29’29.98”E) 


\section{Structured interview}

Quantitative data collection is carried out through structured interviews. The interview was conducted using questionnaires for respondents who were randomly selected. Respondents selected were head of the family with the assumption that the head of the family was considered representative and represented the knowledge of his family. In the quantitative approach, the number of respondents is based on the Frank Lynch formula. Respondents selected proportionally random sampling.

In Ciemas Subdistrict, there are nine villages including Tamanjaya, Mekarjaya, Ciemas, Girimukti, Mekarsakti, Cibenda, Mandrajaya, Ciwaru, and Sidamulya Village. One village that is not selected is Sidamulya Village because this community is a Javanese tribe so that the habits and traditions of the community will be different from other villages which are Sundanese people.

The respondents were chosen through proportionally random sampling, based on the Lynch formula found that the number of respondents in this study was 94 respondents. Based on the number of respondents, as many as 94 respondents and the calculation of the formula proportions obtained the proportion of respondents in each village, including Tamanjaya (12 respondents), Mekarjaya (15 respondents), Ciemas (11 respondents), Girimukti (8 respondents ), Mekarsakti (11 respondents), Cibenda (14 respondents), Mandrajaya (9 respondents), and Ciwaru Village (14 respondents).

\section{Data analysis}

Qualitative data

Qualitative data analysis must pay attention to the consistency of two perspectives, namely the perspective of the informant (emic) and the analysis of the researcher (ethics). Qualitative data are analyzed by cross-checking, summarizing, synthesizing, and descriptive analysis (Newing et al. 2011).

\section{Quantitative data}

Quantitative analysis is carried out after the data collected from interviews with respondents, then analyzed using simple statistics. Simple statistical analysis used is the percentage $(\%)$ of respondents' answer. The percentage of respondents' answer is narrated in a descriptive analysis to describe the data collected descriptively.

\section{RESULTS AND DISCUSSIONS}

\section{Species diversity of animal used}

Based on the results of interviews, there were 153 species of animals used by communities in the Ciemas Subdistrict, both wild and domestic animals (see Table 1). Among 153 species, only 48 species were used by respondents, including insects (1 species), freshwater fish (10 species), crustaceans (4 species), mollusks (1 species), and seawater fish (32 species). Besides, as many as 127 species were used by key informants. The group of animals is used by varied informants, such as insects, seawater and freshwater fish, mollusks, crustaceans, mammals, herpetofauna, and avifauna.

Details of 153 species used by both informants and respondents, including 58 species of Avifauna, 13 species of mammals, 9 species of herpetofauna, 3 species of insects, 16 species of freshwater fish, 43 species of seawater fish, 2 species of mollusks, and 9 species of crustaceans. Several species that are known from key informants are difficult to identify because there is no direct observation on the species that have similarities in local names.

\section{Species utilization in Ciletuh Geopark, Ciemas Subdistrict}

The animals' utilization in Ciletuh Geopark, Ciemas Subdistrict is not evenly distributed in each village (see Table 1). Utilization of Avifauna, Herpetofauna, insects, and mammals tends to be used by the people of Girimukti Village who are close to the forest. Marine fish, crustaceans, and mollusks tend to be utilized by Ciwaru Village communities, while freshwater fish tend to be utilized in each village, except Girimukti and Cibenda Villages. The utilization of marine fish, crustaceans, and mollusks are mostly done in Ciwaru Village because several villages are far from the beach or sea.

Based on the utilization intensity of animals in Ciletuh Geopark, the use of marine fish, mollusks, and some crustaceans are included in the category of Very High (VH) because the catches of marine fish aim to fulfill their daily needs as fishermen. Utilization of other species in the Medium (M) category tends to be used for side consumption needs, such as freshwater fish, poultry, some crustaceans, and mammals to fulfill medicinal needs. The Very Rare (VR) category also tends to be used for side consumption and medicinal needs, such as Avifauna, Herpetofauna, and insect. As medicine sources, mammals and Herpetofauna are not used as the main sources of medicines because other treatments are more easily obtained, such as drugs that are sold on the traditional market, treatment at the health center, and traditional uses of plants.

Based on utilization source, Avifauna and Mammalia tend to be found in the forest, Herpetofauna can be found in settlements or the forest, freshwater fish found in rivers, marine fish and mollusks can be found in the sea, while crustaceans can be found in the sea or even river. The most animal uses come directly from nature, the other animals such as poultry are utilized through cultivation. Other large-scale cultivation in Ciletuh Geopark is the cultivation of shortfin eel (Anguilla bicolor) and giant mottled eel (Anguilla marmorata), precisely in Mandrajaya Village. The collectors take eels that are still small/newly hatched/seeded from estuaries. The harvest of eel is sold to eel farmers in Mandrajaya Village, Cikadal Sub-village. The results of the cultivation are used only on a large scale or large amount which is usually consumed by visitors in Panenjoan, Tamanjaya Village. 


\begin{tabular}{|c|c|c|c|c|c|c|c|c|c|c|c|c|c|c|}
\hline \multirow{2}{*}{ Local name } & \multirow{2}{*}{ Scientific name } & \multicolumn{8}{|c|}{ Villages } & \multirow{2}{*}{$\mathbf{U I}$} & \multicolumn{4}{|c|}{ Utilization form } \\
\hline & & 1 & 2 & 3 & 4 & 5 & 6 & 7 & 8 & & Co & Me & Ac & SV \\
\hline \multicolumn{15}{|l|}{ Avifauna } \\
\hline Asi topi-sisik & Malacopteron cinereum & & & & + & & & & & VR & + & & & \\
\hline Ayam hutan hijau & Gallus varius & & & & + & & & & & VR & + & & & \\
\hline Ayam hutan merah & Gallus gallus & & & & + & & & & & VR & + & & & \\
\hline Ayam kampung & Gallus gallus domesticus & & & & + & & & & & M & + & & & \\
\hline Bebek & Anas sp. & & & & + & & & & & M & + & & & \\
\hline Beluk ketupa & Ketupa ketupu & & & & + & & & & & VR & + & & & \\
\hline Bentet kelabu & Lanius schach & & & & + & & & & & VR & + & & & \\
\hline $\mathrm{BeO}$ & Gracula religiosa & & & & + & & & & & VR & + & & & \\
\hline Betet & Psittacula alexandri & & & & + & & & & & VR & + & & & \\
\hline Blekok & Ardeola speciosa & & & & + & & & & & VR & + & & & \\
\hline Bondol jawa & Lonchura leucogastroides & & & & + & & & & & VR & + & & & \\
\hline Bondol peking & Lonchura punctulata & & & & + & & & & & VR & + & & & \\
\hline Bubut alang-alang & Centropus bengalensis & & & & + & & & & & VR & + & & & \\
\hline Bubut besar & Centropus sinensis & & & & + & & & & & VR & + & & & \\
\hline Caladi tilik & Picoides moluccensis & & & & + & & & & & VR & + & & & \\
\hline Caladi ulam & Dendrocopos macei & & & & + & & & & & VR & + & & & \\
\hline Cangak merah & Ardea purpurea & & & & + & & & & & VR & + & & & \\
\hline Cekakak jawa & Halcyon cyanoventris & & & & + & & & & & VR & + & & & \\
\hline Cekakak belukar & Halcyon smyrnensis & & & & + & & & & & VR & + & & & \\
\hline Cekclek alang-alang & Orthotomus sp. & & & & + & & & & & VR & + & & & \\
\hline Cekclek kaso & Orthotomus sp. & & & & + & & & & & VR & + & & & \\
\hline Cekclek pohon & Orthotomus sp. & & & & + & & & & & VR & + & & & \\
\hline Cipoh kacat & Aegithina tiphia & & & & + & & & & & VR & + & & & \\
\hline Ciung mungkal & Cochoa azurea & & & & + & & & & & VR & + & & & \\
\hline Entog & Cairina moschata & & & & + & & & & & $\mathrm{M}$ & + & & & \\
\hline Gelatik jawa & Padda oryzivora & & & & + & & & & & VR & + & & & \\
\hline Jalak suren & Gracupica contra & & & & + & & & & & VR & + & & & \\
\hline Kadalan birah & Phaenicophaeus curvirostris & & & & + & & & & & VR & + & & & \\
\hline Kareo padi & Amaurornis phoenicurus & & & & + & & & & & VR & + & & & \\
\hline Katik daun & Columbidae & & & & + & & & & & VR & + & & & \\
\hline Katik haji & Columbidae & & & & + & & & & & VR & + & & & \\
\hline Katik harendong & Columbidae & & & & + & & & & & VR & + & & & \\
\hline Katik kebo & Columbidae & & & & + & & & & & VR & + & & & \\
\hline Katik pohon & Columbidae & & & & + & & & & & VR & + & & & \\
\hline Kerak kerbau & Acridotheres javanicus & & & & + & & & & & VR & + & & & \\
\hline Kutilang & Pycnonotus aurigaster & & & & + & & & & & VR & + & & & \\
\hline Limukeun & Chalcophaps indica & & & & + & & & & & VR & + & & & \\
\hline Manintin besar & Enicurus leschenaulti & & & & + & & & & & VR & + & & & \\
\hline Manintin kecil & Enicurus velatus & & & & + & & & & & VR & + & & & \\
\hline Manyar jambul & Ploceus manyar & & & & + & & & & & VR & + & & & \\
\hline Merpati & Columba livia & & & & + & & & & & VR & + & & & \\
\hline Paok pancawarna & Hydrornis guajana & & & & + & & & & & VR & + & & & \\
\hline Perenjak & Prinia flaviventris & & & & + & & & & & VR & + & & & \\
\hline Perkutut & Geopelia striata & & & & + & & & & + & VR & + & & & \\
\hline Pijantung besar & Arachnothera robusta & & & & + & & & & & VR & + & & & \\
\hline Pipit & Anthus novaeseelandiae & & & & + & & & & & VR & + & & & \\
\hline Punai gading & Treron vernans & & & & + & & & & & VR & + & & & \\
\hline Puyuh gonggong & Arborophila javanica & & & & + & & & & & VR & + & & & \\
\hline Puyuh semak & Perdicula asiatica & & & & + & & & & & VR & + & & & \\
\hline Rangkong badak & Buceros rhinoceros & & & & + & & & & & VR & + & & & \\
\hline Sepah merah & Aethopyga siparaja & & & & + & & & & & VR & + & & & \\
\hline Serindit jawa & Loriculus pusillus & & & & + & & & & & VR & + & & & \\
\hline Takur bultok & Psilopogon lineatus & & & & + & & & & & VR & + & & & \\
\hline Takur tohtor & Psilopogon armillaris & & & & + & & & & & VR & + & & & \\
\hline Takur ungkut-ungkut & Psilopogon haemacephalus & & & & + & & & & & VR & + & & & \\
\hline Tikukur & Streptopelia chinensis & & & & + & & & & + & VR & + & & & \\
\hline Trinil pantai & Actitis hypoleucos & & & & + & & & & & VR & + & & & \\
\hline Uncal & Macropygia emiliana & & & & + & & & & & VR & + & & & \\
\hline Mammalia & & & & & + & & & & & & & & & \\
\hline Babi hutan & Sus verrucosus & & & & + & & & & & M & & + & & \\
\hline Kancil & Tragulus javanicus & & & & + & & & & & VR & + & & & \\
\hline Kelinci hutan & Lepus nigricollis & & & & + & & & & & VR & + & & & \\
\hline Landak & Hystrix javanica & & & & + & & & & & VR & & + & & \\
\hline
\end{tabular}




\begin{tabular}{|c|c|c|c|c|c|c|c|c|c|c|c|c|c|c|}
\hline Linsang & Prionodon linsang & & & & + & & & & & VR & + & & & \\
\hline Lutung & Trachypithecus auratus & & & & + & & & & & VR & & + & & \\
\hline Macan tutul & Panthera pardus melas & & & & + & & & & & VR & & + & + & \\
\hline Monyet & Macaca fascicularis & & & & + & & & & & VR & & + & & \\
\hline Musang pandan & Paradoxurus hermaphroditus & & & & + & & & & & VR & + & & & \\
\hline Surili & Presbytis comata & & & & + & & & & & VR & & + & & \\
\hline Tikus & Rattus norvegicus & & & & + & & & & & VR & & + & & \\
\hline Trenggiling & Manis javanica & & & & + & & & & & VR & & + & & \\
\hline Tupai kelapa & Tupaia javanica & & & & + & & & & & VR & & + & & \\
\hline \multicolumn{15}{|l|}{ Herpetofauna } \\
\hline Cicak pohon & Draco volans & & & & + & & & & & VR & & + & & \\
\hline Cicak rumah & Hemidactylus frenatus & & & & + & & & & & VR & & + & & \\
\hline Kadal langit & Squamata & & & & + & & & & & VR & & + & & \\
\hline Kadal pohon & Squamata & & & & + & & & & & VR & & + & & \\
\hline Kadal tanah & Squamata & & & & + & & & & & VR & & + & & \\
\hline Kodok rawa & Anura & & & & + & & & & & VR & & + & & \\
\hline Orai kobra belang & Reptilia & & & & + & & & & & VR & & + & & \\
\hline Orai kobra pohon & Reptilia & & & & + & & & & & VR & & + & & \\
\hline Tokek & Gekko gecko & & & & + & & & & & VR & & + & & \\
\hline \multicolumn{15}{|l|}{ Insect } \\
\hline Belalang & Orthoptera & & & & + & & & & & VR & + & & & \\
\hline Kumbang & Coleoptera & & & + & & & + & & & VR & + & & & \\
\hline Tonggeret & Tibicen linnei & & & & + & & & & & VR & + & & & \\
\hline \multicolumn{15}{|l|}{ Freshwater fish } \\
\hline Batak & Neolissochilus thienemanni & & & & & & & & + & M & + & & & \\
\hline Belut sawah & Monopterus albus & + & & + & & & + & & & M & + & & & \\
\hline Cingir putri & Xiphophorus helleri & + & & & & & & & & M & + & & & \\
\hline Gabus & Channa striata & + & & & & & + & & + & M & + & & & \\
\hline Gurame & Osphronemus goramy & & & & & & & & + & M & + & & & \\
\hline Pantau janggut & Esomus metallicus & & & & & & & & + & M & + & & & \\
\hline Lele lokal & Clarias sp. & + & + & & & & + & + & + & M & + & & & \\
\hline Mas & Cyprinus carpio & + & + & & & & + & & + & M & + & & & \\
\hline Mujaer & Oreochromis mossambicus & + & + & & & & + & & + & M & + & & & \\
\hline Nila & Oreochromis niloticus & + & & & & & + & & + & M & + & & & \\
\hline Sapu & Pterygoplichthys sp. & + & & & & & & & & M & + & & & \\
\hline Sepat & Trichogaster sp. & & & & & & & & + & M & + & & & \\
\hline Sidat anjing & Anguilla bicolor & + & & & & & & + & + & M & + & & & + \\
\hline Sidat kembang & Anguilla marmorata & + & & & & & & + & + & M & + & & & + \\
\hline Tawes & Barbonymus gonionotus & & & & & & & & + & M & + & & & \\
\hline Wader & Barbodes binotatus & + & & + & & & + & & + & M & + & & & \\
\hline \multicolumn{15}{|l|}{ Seawater fish } \\
\hline Arwana & Scleropages sp. & & & & & & & & + & VH & + & & & + \\
\hline Baleragas & Xiphias gladius & & & & & & & & + & VH & + & & & + \\
\hline Baracuda & Sphyraena obtusata & & & & & & & & + & VH & + & & & + \\
\hline Bawal & Pampus argenteus & & & & & & & & + & VH & + & & & + \\
\hline Beronang & Siganus javus & & & & & & & & + & VH & + & & & + \\
\hline Bulan-bulan & Megalops cyprinoides & & & & & & & & + & VH & + & & & + \\
\hline Buntal kelapa & Arothron reticularis & & & & & & & & + & VH & + & & & + \\
\hline Buntal landak & Tetraodon sp. & & & & & & & & + & VH & + & & & + \\
\hline Buntal pisang & Tetraodon lunaris & & & & & & & & + & VH & + & & & + \\
\hline Capungan & Pterapogon sp. & & & & & & & & + & VH & + & & & + \\
\hline Cawang & Leptomelanosoma indicum & & & & & & & & + & VH & + & & & + \\
\hline Cunang & Congresox talabon & & & & & & & & + & VH & + & & & + \\
\hline Deleus & Decapterus sp. & & & & & & & & + & VH & + & & & + \\
\hline Hiu bangbara & Carcharhinus albimarginatus & & & & & & & & + & VH & + & & & + \\
\hline Hiu botol & Centroscymnus crepidater & & & & & & & & + & VH & + & & & + \\
\hline Hiu lutung & Alopias sp. & & & & & & & & + & VH & + & & & + \\
\hline Hiu monyet & Alopias pelagicus & & & & & & & & + & VH & + & & & + \\
\hline Hiu petong & Elasmobranchii & & & & & & & & + & VH & + & & & + \\
\hline Janggilus & Istiophorus sp. & & & & & & & & + & VH & + & & & + \\
\hline Kakap merah & Lutjanus malabaricus & & & & & + & & & + & VH & + & & & + \\
\hline Kawa & Euthynnus affinis & & & & & & & & + & VH & + & & & + \\
\hline Kembung & Rastrelliger brachysoma & & & & & & & & + & $\mathrm{VH}$ & + & & & + \\
\hline Keong laut & Neverita didyma & & & & & & & & + & $\mathrm{M}$ & + & & & \\
\hline Kerapu lodi & Epinephelus sp. & & & & & & & & + & M & + & & & + \\
\hline Kuresi & Nemipterus japonicus & & & & & & & & + & VH & + & & & + \\
\hline Layang & Decapterus sp. & & & & & & & & + & VH & + & & & \\
\hline
\end{tabular}




\begin{tabular}{|c|c|c|c|c|c|c|}
\hline Layur & Trichiurus savala & + & + & $\mathrm{VH}$ & + & + \\
\hline Mata goyang & Priacanthus tayenus & & + & $\mathrm{VH}$ & + & + \\
\hline Mata lembu & Turbo setosus & & + & $\mathrm{M}$ & + & \\
\hline Pari & Trygon sephen & & + & VH & + & + \\
\hline Peda & Thryssa mystax & & + & VH & + & + \\
\hline Pepetek & Leiognathus sp. & & + & VH & + & + \\
\hline Pogot & Aluterus monoceros & & + & VH & + & + \\
\hline Selayang & Decapterus sp. & + & + & VH & + & + \\
\hline Sunglir & Elagatis bipinnulatus & & + & VH & + & + \\
\hline Tembang & Sardinella fimbriata & & + & $\mathrm{VH}$ & + & + \\
\hline Tenggiri & Scomberomorus commerson & & + & $\mathrm{VH}$ & + & + \\
\hline Teri hitam & Stolephorus sp. & & + & VH & + & + \\
\hline Teri katak & Stolephorus sp. & & + & VH & + & + \\
\hline Teri medan & Stolephorus sp. & + & + & VH & + & + \\
\hline Toka-toka & Brevitrygon walga & & + & VH & + & + \\
\hline Tongkol kedaung & Euthynnus sp. & & + & VH & + & + \\
\hline Tongkol kue & Euthynnus sp. & + & + & VH & + & + \\
\hline \multicolumn{7}{|l|}{ Mollusca } \\
\hline Cumi & Loligo sp. & + & + & VH & + & + \\
\hline Gurita & Octopus sp. & & + & VH & + & + \\
\hline \multicolumn{7}{|l|}{ Crustaceae } \\
\hline Kepiting batu & Thalamita sima & & + & M & + & \\
\hline Kepiting sawah & Parathelphusa convexa & & + & M & + & \\
\hline Kepiting bakau & Scylla sp. & & + & M & + & \\
\hline Kepiting merah & Carpilius convexus & & + & M & + & \\
\hline Kepiting rajungan & Portunus pelagicus & & + & $\mathrm{M}$ & + & + \\
\hline Udang & Crustaceae & + & + & VH & + & + \\
\hline Udang galah & Macrobrachium rosenbergii & + & + & $\mathrm{VH}$ & + & + \\
\hline Udang rebon & Mysis relicta & & + & VH & + & + \\
\hline Yutuk batok & Hippa adactyla & & + & VH & + & \\
\hline
\end{tabular}

Notes: +: present. 1. Tamanjaya Village, 2. Mekarjaya Village, 3. Ciemas Village, 4. Girimukti Village, 5. Mekarsakti Village, 6. Cibenda Village, 7. Mandrajaya Village, 8. Ciwaru Village. UI: Utilization Intensity, VR: Very rare, M: Medium, VH: Very high, Co: Consumption, Me: Medicine, Ac: Accessories, SV: Sale value. Utilization Form (Purwanto 2009, modified into categories for animal use): (i) Very High ( $\mathrm{VH}$ ): Including the species of animals that are used in everyday life, usually regularly every day in fulfilling the needs of life. (ii) High $(\mathrm{H})$ : Including the species of animals used in everyday life, used regularly daily, seasonally, or periodically. (iii) Medium (M): Regular use of animal species but at certain times, for example, seasonal uses. Usually, these species are used as medicine or traded if the have excessive results. (iv) Low (L): Covering the species that are rarely used and have no influence on people's daily lives. (v) Very Rare (VR): The intensity of its use, including the species of animals that are very minimal or very rarely used in everyday life.

Based on the form of animal utilization as medicine, it is dominated by Herpetofauna and mammals species, while the others are used as consumption needs. Marine fish usually used for sale. The body part of the species used varies, such as the tongue, tooth, meat, internal organs, depending on the species that is used. Animals and their products derived from animal body organs are part of the supply of medicinal ingredients that have been widely used by society since ancient times (Unnikrishnan 1998 in Badge and Jain 2013). According to Costa-Neto (2005) in Afriyansyah et al. (2016), animals that are used as traditional medicine are usually dead animals. The animals that are used as traditional medicine, including meats, horns, bones, tails, feathers, nails, fat, bile, and shells. The animal products that can be used as traditional medicine are urine, feces, honey, and milk.

Utilization of mammals only is carried out by certain people who can hunt because not easy to hunt mammals. Mammals species that are used as medicine are nine species, including wild boar's bile (reducing asthma), porcupine's stomach (eliminating the fishy smell of blood in mothers who have given birth, as antibiotics, and cleansing body excrement), langur's meat (as antibiotics), monkey's meat (as an antibiotic), Pangolin's scales (treat all kinds of diseases), leopard's internal organs (tongue: treat heart and lung disease; bones: antibiotics; meat: anti-fever), grizzled monkey's meat (as antibiotics), meat of rat puppies (treat fever), Horsfield's treeshrew's meat (diabetes that requires at least four tails, and treats fever).

Mammals species that are used for consumption are four species, including banded linsang, common palm civet, Indian hare, and Javan mouse deer. Those species are used because they have high selling value, including leopard and pangolin at IDR $1,700,000 / \mathrm{kg}$. The species that are used as accessories include leopard tongue as a talisman and leopard tooth as a necklace. In the processing, most of them are carried out by burning for the species that are used as medicine. The combustion process is chosen rather than fried, because it will keep the nutrients in the body, unlike the frying process, the nutrients will disappear and reduce the efficiency to cure the disease. Especially for this species of mouse, it is skinned first, washed, then eaten immediately without cooking processing.

In Cisokan, Pangolin's meat used for self-consumption and its scale could be used as repellent lemur pest in rice field. During the early 2000, local people began to 
understand that Pangolin's scales have a high economic value, and the hunting activities started to change its purpose from self-consumption to commercial. Scale price could be as high as IDR $100.000 / \mathrm{kg}$, whie living Pangolin could reach IDR 200.000-250.000/kg. Pangolin hunter sold at the average price of IDR $300.000 / \mathrm{kg}$ in Sukabumi and Cianjur Regencies (Withaningsih et al. 2018).

Local people in Cisokan also hunted porcupine as if the expel a pest. Some of them kill it and make it a meal (Mustikasari et al. 2019). In Malaysia, porcupine meat was popular as an alternative meat product in the domestic market. Half of Malaysian urban consumers acknowledged that porcupine meat can be eaten (halal) and has high nutritional values (Norsuhana et al. 2012). In Singapore, bezoars of porcupine are the most popular and it can be one of the main causes of overhunting (Chung et al. 2016).

Based on a study conducted by Partasasmita et al. (2016) regarding leopard utilization, Girimukti Village uses leopards as a medicine for skin diseases by applying leopard ash from the burning to the skin and recovering so that the community knows that leopards have benefits as antibiotics. The hunting of leopards is not because of the needs as a medicine, but the leopard has been disrupting the community by preying on livestock. As a result of leopard hunting, some people collect skins and mustaches in 2013 as private collections. In addition, several body parts that are utilized as bone have a selling value of IDR $250,000 / \mathrm{kg}$ and use as medicines, teeth for amulets, nails as accessories for necklaces decorated with gold, liver, and bile as antibiotics, the brain to cure lungs and heart diseases, heart to cure asthma, and skin has a high selling value, costing IDR 2,500,000 to IDR 6,000,000 as a talisman or home decoration, and a tongue for IDR $1,000,000$ as a talisman.

Nine species of Herpetofauna also used as medicine including cicak pohon's meat and cicak rumah (fever medicine), meat in kadal langit, kadal pohon, kadal tanah, and geckos (medicine for skin diseases such as eczema, scabies, and ringworm), kodok rawa's meat (medicine for asthma), bile in ular kobra belang and ular kobra pohon (medicine for all kinds of diseases). Not everyone can consume reptiles or amphibians and only be done by certain people who can hunt especially snakes and are not easy to hunt snakes because they are considered dangerous. The processing of Herpetofauna to be consumption is carried out by burning.

\section{Utilization of species in each village}

Based on Table 1 that animal utilization by respondents (94 respondents) in Ciletuh Geopark, Ciemas Subdistrict, Sukabumi is dominated by freshwater fishes in several villages, such as local catfish (Clarias sp.), Common carp (Cyprinus carpio), the Mozambique tilapia (Oreochromis mossambicus), and spotted barb (Barbodes binotatus). The utilization of these freshwater fishes is mostly done because it is easy to obtain, besides that the river as the location for catching the fish is near the settlement. The use of these fishes is carried out to fill spare time and protein needs for the family.
The dominant species are used by respondents, including local catfish used by nine respondents, common carp, the Mozambique tilapia, and spotted barb with each utilized by six respondents. Although marine fish, mollusks, and crustaceans are used every day with a large number of species, freshwater fish are more often used by many people in the Ciemas Subdistrict. This is because only a small number of the people who work as fishermen in Ciemas Subdistrict, not all people can take the time to sail to the sea, and the operational costs of the ship are quite expensive. Unlike fishing in the river that can be done near the settlement and at any time without paying a fee.

Most people in Ciemas Subdistrict do not use mammals, Herpetofauna, insects, and Avifauna because most of the land use in Ciemas Subdistrict was dominated by rice fields, swidden cultivation, and plantations. This certainly affects the livelihoods of the community dominated as farmers and seldom people who use species from the forest, so there is no local knowledge about the utilization of species, especially species from the forest. People don't go to the forest because their needs have been fulfilled by the existence of the traditional market if they want to buy cooking fuel, health centers if they are sick and rarely use traditional materials. Because of these modernization factors, people's knowledge of natural use will be lost over time. Besides, there are still easier options for using other species, such as poultry.

Indigenous ethnicities around the world believe that ingredients derived from animals can cure diseases without the need to prove them from scientific aspects. Jain et al. (2009) in Zubaidah et al. (2012) states that every tribe or tribal community has extensive knowledge about drugs derived from nature, especially drugs derived from animals and plants.

According to Afryansyah et al. (2016) that the use of animals for drugs and food ingredients. These animals include goats, cows, eels, the striped snakehead, domestic chickens and catfishes. This is also stated by Ferreira et al. (2009) regarding local perception in Dinoyo Malang Village that Iguana iguana (common iguana), Bos taurus (cow), Gallus domesticus (chicken) are animals that can be used as food. This indicates that the importance of biodiversity as sources of treatment and nutritional products.

\section{Comparison of previous study results}

Several species found both through direct encounters and interview studies on biodiversity studies by the University of Padjadjaran in 2017 in Ciemas Subdistrict. The number of species based on interviews by UNPAD (2017) unpublished, compare with this study on animal utilization, including four species of avifauna and eight species of mammals. The number of species found directly, including 28 species of avifauna, nine species of mammals, three species of Herpetofauna, three freshwater fish, and two species of marine fish. In a study conducted by Ramadhani (2018) unpublished, examined the knowledge of the Avifauna found 39 species in Girimukti Village based on local knowledge and 15 species were found directly. Information on the existence of a number of these 
species is known to have a function in the use of both consumption and non-consumption which was explained in this study.

As explained by Ramadhani (2018) unpublished, based on interviews with poachers, the extinct species of Avifauna as many as two species but they have been used, including green junglefowl (Gallus varius) and rhinoceros hornbill (Buceros rhinoceros), while eight species of Avifauna are rarely found, including red junglefowl (Gallus gallus), red-breasted parakeet (Psittacula alexandri), purple heron (Ardea purpurea), white-breasted kingfisher (Halcyon smyrnensis), Asian pied starling (Gracupica contra), breasted malkoha (Phaenicophaeus curvirostris), emerald dove (Chalcophaps indica), and Javan banded pitta (Hydrornis guajana). Besides, the utilization of Avifauna has been decreased because of community regulations regarding the prohibition of hunting avifauna, especially in Girimukti Village.

Herpetofauna species found a few numbers because some local names cannot be identified until Latin naming, so it cannot be compared with other studies. Direct encounters with freshwater and marine fish, insects, and crustaceans are few, due to studies by UNPAD (2017) unpublished, tend to focus on Avifauna, Mammalia, and Herpetofauna. This direct encounter shows that the species used by the Ciemas Subdistrict community are found in nature.

\section{Knowledge resources on species utilization}

Sources of the communities knowledge about animals utilization can be seen in Figure 2. Sources of local knowledge about the use of animals can be seen in Figure 2. The highest source of knowledge is obtained from personal, such as freshwater fish that can be consumed. Sources of knowledge about the use of mammals, insects, Avifauna, and Herpetofauna are obtained from the knowledge of parents who are passed on to the next generation. Sources of knowledge about the use of marine fish, mollusks, and crustaceans are obtained from neighbors, even though there is a knowledge of the use of them from parents. Others, N/A (not available) are people who don't utilize the fauna species.

Local knowledge derived by parents is relatively small compared to the knowledge that comes from personal/own experience. This certainly affects the loss of important knowledge about traditional animal knowledge from generation to generation. According to Zulkarnain and Franto (2014) in Afryansyah et al. (2016) on the study of ethnic Lom in Bangka that Lom ethnic knowledge is derived from parenting, exchanging ideas with community members, and the results of their own experiences. This means that this knowledge is only delivered orally from generation to generation in the community concerned, so that knowledge will be threatened with extinction.

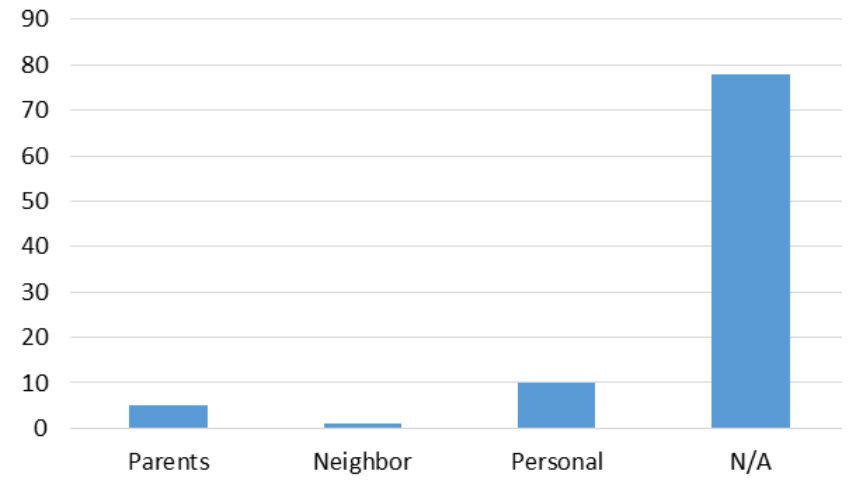

Figure 2. Sources of knowledge about animals utilization in Ciemas Subdistrict, Sukabumi, West Java

In conclusion, the community of Ciemas Subdistrict uses 153 species, consisting 58 species of Avifauna, 13 species of mammals, nine species of herpetofauna, three species of insects, 16 species of freshwater fish, 43 species of marine fish, two species of mollusks, and nine species of crustacea. Utilization of fauna species in Ciletuh Geopark, Ciemas Subdistrict is not distributed in each village. Animal using of Avifauna, herpetofauna, insects, and mammals tends to be used by people of Girimukti Village. Marine fish, mollusks, and crustacean tend to be utilized by people of Ciwaru Village, while freshwater fish tend to be used in each village, except Girimukti and Cibenda Village. Utilization of fauna species in Ciemas Subdistrict has begun to be abandoned, although several people still use them.

\section{ACKNOWLEDGEMENTS}

Thank you to the ALG (Academic Leader Grant) Prof. Dr. Erri Noviar Megantara, CESS (Center for Environmental and Sustainability Science) of Padjadjaran University, PAPSI staff (Paguyuban Alam Pakidulan Sukabumi), informants and respondents of Ciemas Subdistrict, and surveyor team.

\section{REFERENCES}

Afriyansyah B, Nur AH, Hapis A. 2016. Utilization of animals as traditional medicines by Lom ethnic in Bangka. J Sci Res 18 (2): 6674.

Albuquerque UP, Luiz VFCC, Reinaldo FPL, Romulo RNA. 2014. Methods and techniques in ethnobiology and ethnoecology. Springer Protocols Handbooks. Humana Press. New York.

Badge N, Jain S. 2013. Ethnozoological studies and medicinal values of vertebrate origin in the adjoining areas of Pench National Park of Chhindwara District of Madhya Pradesh, India. Intl J Life Sci 1 (4): 278-283.

Central Bureau of Statistics of Ciemas Subdistrict. 2017. Ciemas Subdistrict in 2017. Central Bureau of Statistics of Sukabumi District. Sukabumi. [Indonesian]

Chung YF, Lim NTL, Shunari M, Wang DJ, Chan SKL. 2016. Records of the Malayan porcupine, Hystrix brachyura (Mammalia: Rodentia: Hystricidae) in Singapore. Nature in Singapore 9: 63-68.

Creswell JW. 2009. Research design: qualitative, quantitative, and mixed methods approach. SAGE Publication, Inc. California 
Ferreira FS, Brito SV, Ribeiro SC, Almeida WO, and Alves RRN. 2009 Zootherapeutics utilized by residents of the community Poco Dantas, Crato-CE, Brazil. J Ethnobiol Ethnomed 5: 21. DOI: 10.1186/17464269-5-21.

Husodo T, Sya Sya S, Puput F, M Pahla P, Erri NM. 2019. Mammalian Diversity in West Java, Indonesia. Biodiversitas. 20 (7): 1846-1858.

Iskandar J, Budiawati SI, Ruhyat P. 2016. Responses to Environmental and Socio-economic Changes in the Karangwangi Traditional Agroforestry System, South Cianjur, West Java. Biodiversitas. 17 (1): 332-341.

Mustikasari IA, Susanti W, Erri NM, Teguh H, Parikesit. 2019. Population and Distribution of Sunda Porcupine (Hystrix javanica $\mathrm{F}$. Cuvier, 1823) in Designated Area of Cisokan Hydropower, West Java, Indonesia. Biodiversitas. 20 (3): 762-769.

Newing H, Eagle CM, Puri RK, and Watson CW. 2011. Conducting research in conservation: a social science perspective. Routledge, London.

Norsuhana AH, Shukor MN, Aminah A. 2012. Perceptions on captive malayan porcupine (Hystrix brachyura) Meat by Malaysian urban consumers. Health Environ J 3 (1): 67-78.

Partasasmita R, Sya Sya S, Johan I, Erri NM, Teguh H, Parikesit, Nicholas M. 2016. Human-Leopard Conflict in Girimukti Village, Sukabumi, Indonesia. Biodiversitas. 17 (2): 783-790.

Purwanto Y, Waluyo EB, Afriastini JJ. 2009. A cultural value analysis of non-wood forest products for potential valuation and possible development. Indonesian Institute of Science. Jakarta.
Withaningsih S, Fathimah N, Erri NM, Parikesit, and Teguh H. 2018. Nest Existences and Population of Pangolin (Manis javanica Desmarest, 1822) at the Designated Area of Cisokan Hydropower, West Java, Indonesia. Biodiversitas. 19 (1): 153-162.

Wulandari I, Randi H, Teguh H, Erri NM. 2018. Vegetation Structure and Composition in Ciletuh Geopark, Sukabumi, Indonesia. Asian Journal of Forestry. 2 (2): 54-61.

Zubaidah S, Norhusana AH, Hamamah FY. 2012. Use of animals for traditional medicines among indigenous people in Asia: one review. Malaysian J Society and Space. 8 (3) : 52-60.

Unpublished:

UNPAD [Padjadjaran University]. 2017. Biodiversity Management in Ciletuh Geopark. Academic Leadership Grant. Faculty of Mathematics and Natural Sciences, Padjadjaran University, Sumedang. Unpublished. [Indonesian]

Gunawan, EF. 2018. Plant Utilization based on Local Knowledge in Ciletuh Geopark, Sukabumi. [Hon. Thesis]. Program of Biology, Faculty of Mathematics and Natural Sciences, Padjadjaran University, Sumedang. Unpublished. [Indonesian]

Ramadhani, HS. 2018. Local Knowledge of Rural People on Species Diversity, Role and Conservation of Bird in Girimukti Village Subdistrict, Ciemas Subdistrict, Sukabumi, West Java. [Hon. Thesis]. Program of Biology, Faculty of Mathematics and Natural Sciences, Padjadjaran University, Sumedang. Unpublished. [Indonesian]. 